\title{
Delipidation and Deproteination of Coconut Dregs Fermented with Aspergillus niger to Produce Prebiotic compounds
}

\author{
Bahri S, * \\ Department of Chemistry Faculty Mathematics and Natural Sciences, University of Tadulako \\ B. Sundu, \\ Department of Animal Husbandry, University of Tadulako, Palu, Indonesia \\ Damry H.B., \\ Department of Animal Husbandry, University of Tadulako, Palu, Indonesia \\ Gatot Siswo Hutumo \\ Department of Agriculture, University of Tadulako, Palu, Indonesia
}

\begin{abstract}
Coconut dregs are the waste product of oil extraction, either to produce conventional cooking oil or virgin coconut oil (VCO). These coconut dregs contain mannan compound in the form of galactomannan. Fermentation of this compound could generate mannan-oligosaccharides, having prebiotic properties, due to the presence of mannanase enzyme during fermentation. A study on fermentation of coconut dregs was carried out with a delipidation process using n-hexane and deproteination using $\mathrm{NaOH} 1 \mathrm{M}$. The fermentation process was done using Aspergillus niger with different duration of fermentation (48, 72, 96, 120 and 144 hours). The fermentation product was placed in the free-air container to kill the fungi and keep the biodegradation process through enzymatic process for $0,24,48$ and 72 hours. The products were tested for prebiotic properties through spread plate method using Lactobacillus casei and Escherichia coli. The results of the delipidation process could decreased lipid content to $0.77 \%$ and the deproteination process could bring down crude protein of coconut dregs to $1.45 \%$. The highest mannanase activity was found when coconut dregs were fermented for 120 hours with a value of $1.0331 \mathrm{U} / \mathrm{ml}$. Hydrolyzate produced during incubation had a prebiotic activity by increasing the population Lactobacillus casei and decreasing population of Escherichia coli. Lactobacillus casei bacteria increased from $2 \times 10^{7} \mathrm{CFU} / \mathrm{ml}$ to between $30.6 \times 10^{7} \mathrm{CFU} / \mathrm{ml}$ and $35.0 \times 10^{7} \mathrm{CFU} / \mathrm{ml}$, whereas Escherichia coli bacteria decreased from $2 \times 10^{7} \mathrm{CFU} / \mathrm{ml}$ to between $5.3 \times 10^{6} \mathrm{CFU} / \mathrm{ml}$ and $8.3 \times 10^{6} \mathrm{CFU} / \mathrm{ml}$.
\end{abstract}

Keywords: Coconut dregs, Aspergillus niger, Prebiotics

DOI: $10.7176 / \mathrm{JBAH} / 10-6-03$

Publication date:March $31^{\text {st }} 2020$

\section{Introduction}

Coconut is a tropical plant that grows in many Asian and Pacific countries. In 1987, around $82 \%$ of the world's coconut production derived from the Asian and Pacific. While the rest of the products were from Africa and the United States (Suhardiyono, 1988). (Prastowo, et al., 2007) reported that coconut production in Indonesia averaged 15.5 billion nuts per year. The production of coconuts was quite stable every year and has even increased from 2000 to 2011. The coconut production increased significantly in the range between 3044 to 3174 million tons/year (Sarjono, et al., 2013).

Coconut meat was generally processed into coconut milk (juice extract) with/without the addition of water. The waste product of producing coconut milk through the wet process was called as "coconut dregs". The amount of coconut dregs obtained from every 100 coconuts to produce coconut milk was $19.50 \mathrm{~kg}$ (Meddiaty, 2010). Khuwijitjaru et.al., (2012) reported that coconut dregs contain $68.99 \%$ carbohydrate, consisting of 79.77\% mannose, 12.80 glucose, 6.12\% galactose and 1.31\% arabinose. Miskiyah (2010) also reported that coconut dregs contained $11.35 \%$ protein, $14.97 \%$ crude fiber, $23.36 \%$ crude fat, $11.31 \%$ moisture content and $3.04 \%$ ash content.

Ariandi et al. (2015), reported that Hydrolysis of galactomannan in copra meal was done by mannanases derived from microorganisms Streptomysessp BF3.1. This process obtained generated manno-oligosaccharide compounds. The optimum conditions for mannanase activity were at $70^{\circ} \mathrm{C}$ and $\mathrm{pH}$. The results of the analytical products analysed by thin-layer chromatography (TLC) and High Performance Liquid Chromatography (HPLC) indicated that in the hydrolysis products there were 5 types of manno-oligosaccharide (MOS) compounds, namely manno-disaccharides, manno-trisaccharides, manno-tetrasaccharides, manno-pentasaccharides and manno-hexosaccharides. Lee (2007) in his research reported that the enzyme mannanase can be produced from several types of microorganisms. The microorganisms are Aspergillus wentii TISTR 3075, Aspergilusniger, Aspergilusoryzae, Trichodermareesei TISTR 3080, and Penecilium sp. His research was carried out using a palm 
kernel cake substrate, with the highest mannanase activity as obtained from Aspergilusniger bacteria, $2.02 \mathrm{U} / \mathrm{ml}$ (Ariandi et al., 2015).

Mannanase could be produced from various types of Aspergillus niger using the solid fermentation method (Felicia et al., 2013). The activity of the mannanase enzyme produced from the fermentation process was 1.21 $\mathrm{U} / \mathrm{mg}$. After the purification process using ion-exchange chromatography, the activity increased to $19.091 \mathrm{U} / \mathrm{mg}$. Maximum activity was obtained under hydrolysis conditions at $\mathrm{pH} 5.5$ and temperature at $30^{\circ} \mathrm{C}$ (Felicia et al., 2013). In a solid fermentation system, the microorganisms grow in conditions according to their natural habitat. However, in these conditions, the metabolic processes produced are more efficient and better enzymes compared to liquid fermentation. In addition, solid fermentation has many advantages compared to liquid fermentation, namely a high level of productivity, a simpler technique, relatively low cost used, low energy requirements, a small amount of water discharged, better product recovery. (Tanyildizi et al., 2007).

The research of Ishihara et al. (2000) showed that the addition of manno-oliogsaccharides (MOS) orally to broilers and laying hens were able to reduce Salmonella enteritidis and increase the number of Bifidobacterium spp. and Lactobacillus spp. The optimum level of MOS in this study was $0.025 \%$ of the ration. These oligosaccharides can also increase non-specific mucosal protection by increasing the relative number of goblet cells and mucus secretion and increasing the beneficial bacterial colonies (Ferket et al., 2002). Turner et al. (2000) showed a beneficial effect of MOS compounds on the health status of the digestive tract and the immune system. An in-vitro study indicated that Salmonella typhimurium was inhibited by the presence of mannose compounds. The administration of MOS through drinking water in chickens reduced the colonization of Salmonella typhimurium in the caecum. Furthermore, the use of MOS increased plasma IgG levels and IgA concentrations in bile of turkey.

\section{Materials and methods}

\subsection{Material}

The basic ingredients used in this study were coconut dregs, Escherichia coli bacteria. Lactobacillus casei, glucose, Potato Dextrose Agar (PDA) medium, Potatoes Dextrose Broth (PDB), Sodium Agar (NA), NaCl, alcohol, phosphate buffer, Aspergillus niger, $\mathrm{NaOH}$, n-hexane (Merck), potatoes, sugar, K2HPO4 (Merck), $\mathrm{MgSO}_{4} .7 \mathrm{H}_{2} \mathrm{O}$ (Merck), $\mathrm{H}_{3} \mathrm{PO}_{4}$ (merckKGaA) $\mathrm{CaCl}_{2}, \mathrm{NaNO}_{3}, \mathrm{FeSO}_{4} .7 \mathrm{H}_{2} \mathrm{O}$ (Merck), ZnSO4 (Merck), and $\mathrm{MnSO}_{4}$ (Merck), locust bean gum, DNS (Merck), butanol, acetic acid, sulfuric acid, acetone, aniline, and $\mathrm{pH}$ indicator

\subsection{Equipment}

The equipments used in the study were incubators (Pol-Eko Aparatura), Kjedhal (Kjedhaterm), Sockets, funnel Buchner, vacuum pump, oven (Memmert), petri dish, spread plate, shake machine, analytical balance (Memmert), laminar water flaw (Esco Class II BSC), thermoshaker (Gerhardt), spectrophotometer UV-VIS (PerkinElmer), autoclaves, water baths (Memmert), refrigerators, microscopes, hemasytometer, plastics, and other glassware commonly used in Chemistry Laboratories

\subsection{Delipidation and Deproteination Process}

\subsubsection{Coconut Dregs Delipidation (Phanwipa et al., 2015 modification)}

Coconut dregs were repeatedly washed using warm water temperature with of $50^{\circ} \mathrm{C}$, until a clear colored solution was obtained. The residue of coconut dregs was collected in a container and dried. The $1 \mathrm{~kg}$ of dried coconut dregs was added $10 \mathrm{ln}$-hexane, stirred and macerated for 24 hours. The level of fat of coconut dregs was determined before and after delipidation by socletation method.

\subsubsection{Deproteination of Coconut Dregs}

Fat-free coconut dregs were further processed for the deproteination process using modified Kusakabe and Takashi (1988) methods. A total of $1 \mathrm{~kg}$ of fat-free coconut dregs was put into a container and added $\mathrm{NaOH} 1 \mathrm{M}$ with volume ratio $1: 10,1: 12,1: 14,1: 16,1: 18$ and $1: 20$. The mixture was left for 24 hours with occasional stirring so that the reaction process run well. This process was carried out at room temperature. After 24 hours, the mixture was then filtered and determined its protein content before and after deproteination by the kjeldahl method.

\subsubsection{Incubation time of coconut dregs}

Fat free coconut dregs and protein as much as $1 \mathrm{~kg}$ was added with a buffer solution of $\mathrm{pH} 9$ (Bahri et al., 2019) containing minerals $\left(\mathrm{K}_{2} \mathrm{HPO}_{4} 15.3 \mathrm{~g}, \mathrm{MgSO}_{4} .7 \mathrm{H}_{2} \mathrm{O} 3.3 \mathrm{~g}, \mathrm{CaCl}_{2} 0.3 \mathrm{~g}, \mathrm{NaNO}_{3} 3.3 \mathrm{~g}, \mathrm{FeSO}_{4} .7 \mathrm{H}_{2} \mathrm{O} 0.6 \mathrm{~g}, \mathrm{ZnSO}_{4}\right.$ $0.13 \mathrm{~g}, \mathrm{MnSO}_{4} 0.8 \mathrm{~g}$ ). The mixture was autoclaved, then cooled to $\pm 70^{\circ} \mathrm{C}$. The buffer solution was added with $10^{6}$ Aspergillus niger. The buffer and coconut dregs were mixed with a buffer: coconut dregs ratio of $2: 1(\mathrm{w} / \mathrm{v})$ or water content of $50 \%$. After evenly stirring, the solution was put in a plastic bag with incubated time variations of 48, 72, 96, 120 and 144 hours (Felisia et.al 2012). Each treatment was tested for mannanase activity using Locus Bean Gum substrate. Sugar compounds produced were analyzed using the DNS method (Miller, 1959). 


\subsection{Fermentation Product Enzymatic Reaction Process}

Fat and protein-free coconut dregs as much as $1 \mathrm{~kg}$ was added to the buffer solution pH 9 (Bahri et al., 2019) containing minerals $\left(\mathrm{K}_{2} \mathrm{HPO}_{4} 15.3 \mathrm{~g}, \mathrm{MgSO}_{4} .7 \mathrm{H}_{2} \mathrm{O} 3.3 \mathrm{~g}, \mathrm{CaCl}_{2} 0.3 \mathrm{~g}, \mathrm{NaNO}_{3} 3.3 \mathrm{~g}, \mathrm{FeSO}_{4} .7 \mathrm{H}_{2} \mathrm{O} 0,6 \mathrm{~g}\right.$, $\mathrm{ZnSO}_{4} 0.13 \mathrm{~g}, \mathrm{MnSO}_{4} 0.8 \mathrm{~g}$ ). The mixture was autoclaved, then cooled to $\pm 70^{\circ} \mathrm{C}$. The buffer solution was added $10^{6}$ Aspergillus niger. The buffer and coconut dregs were then mixed with a buffer: coconut dregs ratio of 2:1 (w $/ \mathrm{v}$ ) or water content of $50 \%$ (Felicia et al., 2012). The mixture was stirring evenly distributed and put in a plastic bag. Furthermore, it was incubated for 120 hours. The fermentation product is vacuum and stored at room temperature and incubation time variations $(0,24.48$ and 72 hours). The fermentation product was added distilled water at $100^{\circ} \mathrm{C}$ to extract the compound, as well as to stop the enzyme reaction for 30 minutes. The filtrate was filtered, stored in a cool place at $4^{0} \mathrm{C}$. This filtrate is then used for prebiotic testing of Eschericheacoli bacteria and Lactobacillus casei (Supriyati et al., 1998).

\subsection{Prebiotic Test for Fermented Extract with Escherichia bacteria. Coli and lactobacillus casei}

Escherichea coli and Lactobacillus casei were grown in MRS base liquid media. A total of $4 \mathrm{ml}$ of a solution containing bacteria was added with $1 \mathrm{ml}$ of fermentation extract solution. The solution was stirred and left for 5 minutes. A $0.1 \mathrm{ml}$ of the solution was taken from the top solution with a micropipette and inserted in a test tube that has been sterilized. Bacteria in the tube were diluted to $10^{-5}$. Furthermore, it was put into NA media using the spread plate method and incubated for 48 hours at room temperature.

\section{Results and Discussion}

\subsection{Fat content Coconut dregs after delipidation}

The result of the initial research of coconut dregs before the process of delipidation using hexane compounds was $37.13 \%$. The delipidation process by the method of immersion (maceration) using n-hexane solvent for 24 hours, the first stage obtained a fat content of about $6.5 \%$. This fat content was still quite high, so it is necessary to do the maceration process for the second phase 2 for the next 24 hours. The fat content of the residue of coconut dregs in the second phase was $0.77 \%$.

In the process of extracting the chemical components in each substrate, theoretically it cannot extract all the components contained in the sample. This is in accordance with the Nernst Distribution Law, a solute will distribute itself between two materials which do not mix together. So that after the distribution equilibrium is reached, the ratio of concentrations of substances in the two phases at a constant temperature will be a constant, provided that the substance has the same molecular weight in both phases.

Based on the results of the study, the remaining fat content in the coconut dregs was $0.77 \%$. Lipid levels in materials cannot be extracted $100 \%$ in food, because some of these lipid compounds are still bound to other compounds such as proteins to form proteolipids compounds and to carbohydrate compounds to form glycolipids. The possibility of this lipid can run out if the maceration process is carried out by the socletation method, because of the socletation method, n-hexane solvent used in conditions not saturated with fat compounds so that the dissolution process can run well

\subsection{Protein Content of Coconut Dregs After Deproteination}

Protein content in coconut dregs was dissolved with $\mathrm{NaOH}$ as done by Kusakabe and Takashi, (1988). It is intended that all dissolved protein contained in coconut dregs will be extracted into a solution of $\mathrm{NaOH}$. The results of the deproteination process are as shown in Figure 1 below.

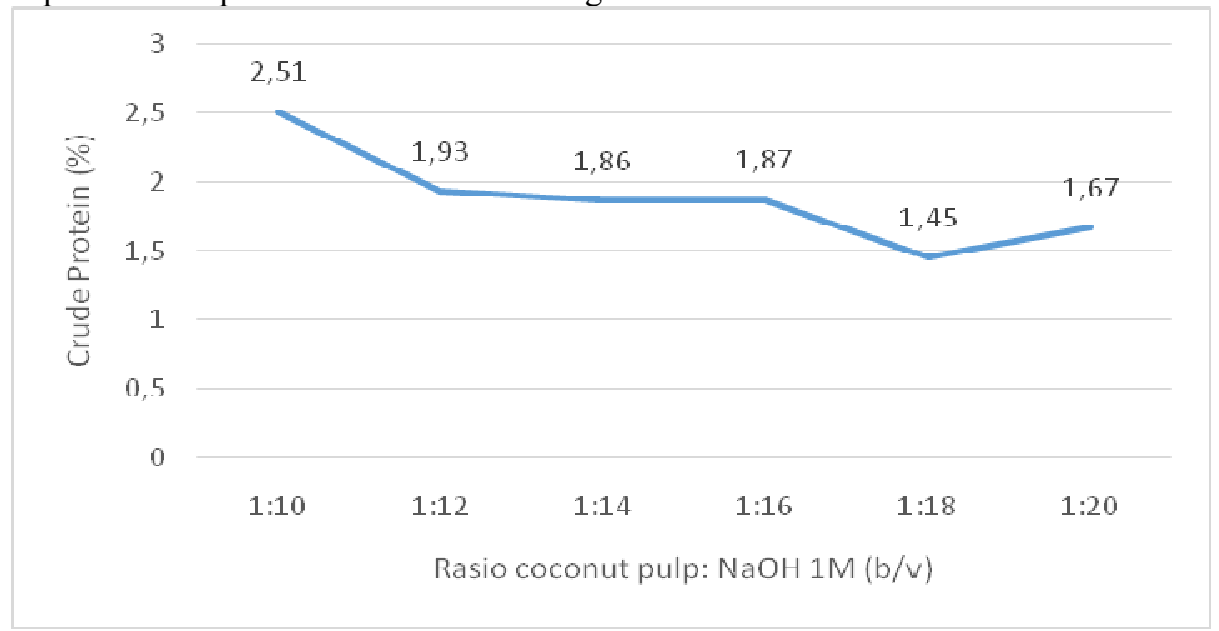

Figure 1. Curve of protein content by comparing the volume of $\mathrm{NaOH}$ 
The coconut dregs which have been extracted its protein with $1 \mathrm{M} \mathrm{NaOH}$ solution had the lowest crude protein content, being $1.45 \%$. This is consistent with research conducted by many researchers, indicating that the protein content in the material will be dissolved in $\mathrm{NaOH}$ well. In this process, there is still total $\mathrm{N}$ in the coconut dregs which is most likely derived from other compounds that contain nitrogen. Deproteination is the process of removing protein content in a substance. In this process, the peptide bond that connects amino acids to protein molecules will be broken through the hydrolysis reaction. Protein solubility will gradually increase if the $\mathrm{pH}$ turns into alkaline. An alkaline solution makes $\mathrm{OH}^{-}$ions bind to the $\mathrm{H}^{+}$ions found in amine groups $\left(\mathrm{NH}_{3}^{+}\right)$in protein molecules. The binding of $\mathrm{H}^{+}$ions to the amine group causes the $\mathrm{OH}^{-}$group in the carboxylate in the protein to form negative ions $\left(\mathrm{COO}^{-}\right)$. The more alkaline the extraction conditions, the greater the concentration of $\mathrm{OH}^{-}$ions which are able to bind $\mathrm{H}^{+}$ions to the $\mathrm{NH}_{2}$ group, so that protein solubility become higher. This is in accordance with the statement of Lehninger (1988), the effect of $\mathrm{pH}$ was based on differences in charge between the amino acids as building blocks of proteins.

According to Lorenzo (2008), high solubility at alkaline $\mathrm{pH}$ leads to protein interactions, commonly carried out at $\mathrm{pH} 10-12$. The isoelectric point value in the $\mathrm{NaOH}$ and $\mathrm{KOH}$ solvent does not vary much and still in the range of the isoelectric point value of the protein. At isoelectric $\mathrm{pH}$, the numbers of positive charge groups and negative charge groups were the same value, so that the protein molecule settles. This is in accordance with the statement Buxbaum (2007) who stated that at the isoelectric point of attraction occurs between the protein molecules that cause aggregation and precipitation of other molecules. According to Vani and Zayas (1995), most vegetable proteins have an isoelectric point at $\mathrm{pH}$ 4.0-5.0. The strongest attractiveness between the same proteins occurs at isoelectric $\mathrm{pH}$, whereas at $\mathrm{pH}$ above and below the isoelectric point, the protein will experience changes in charge which causes a decrease in attractiveness between protein molecules so that protein molecules dissolve easily.

ANOVA test indicating at $95 \%$ confidence level showed a significant effect on crude protein levels found in coconut dregs at 1:10 treatment with other treatments. Tukey Test results show that there are 2 groups of data in the process of deproteination of coconut dregs using $1 \mathrm{M} \mathrm{NaOH}$. Protein content with the ratio of coconut dregs: $\mathrm{NaOH}(1: 10)$ produced the highest levels and was significantly different, whereas for variations of $\mathrm{NaOH}$ $1: 12,1: 14,1: 16,1: 18$ and 1:20 were not significantly different.

\subsection{Mannanase Enzyme Activity Fermentation Time Variation}

3.3.1. Standard Curve Analysis of mannose levels

The levels of mannose from hydrolysis by mannanase enzymes against locust bean gum (LBG) substrates were determined by the spectrophotometer method at a wavelength of $540 \mathrm{~nm}$. The coloring method was the DNS method. The amount of reduced DNS is directly proportional to the concentration of mannose found in the media. Color changes occur in the DNS reagent after reacting with reducing sugar so that the original color turns yellow to reddish-orange, as shown in Figure 2

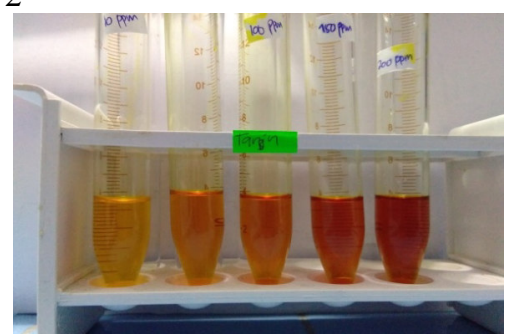

Figure 2. Mannosa's reaction with DNS

The results of the analysis of glucose standard solutions indicate that the higher the concentration of mannose, the higher the absorbance obtained. Manosa is a type of reducing sugars because the aldehyde groups in manoses can be oxidized to carboxyl groups. Glucose level analysis was performed by the method of Miller (1959) using 3,5-dinitrosalicylic acid (DNS) compounds. This compound is an aromatic compound that can react with reducing sugars to form 3,5 diaminosalicylic acid, a compound that can absorb electromagnetic radiation at a wavelength of $540 \mathrm{~nm}$. The number of 3.5 diaminosalicylic acid molecules formed depends on the amount of reducing sugar in a sample. 


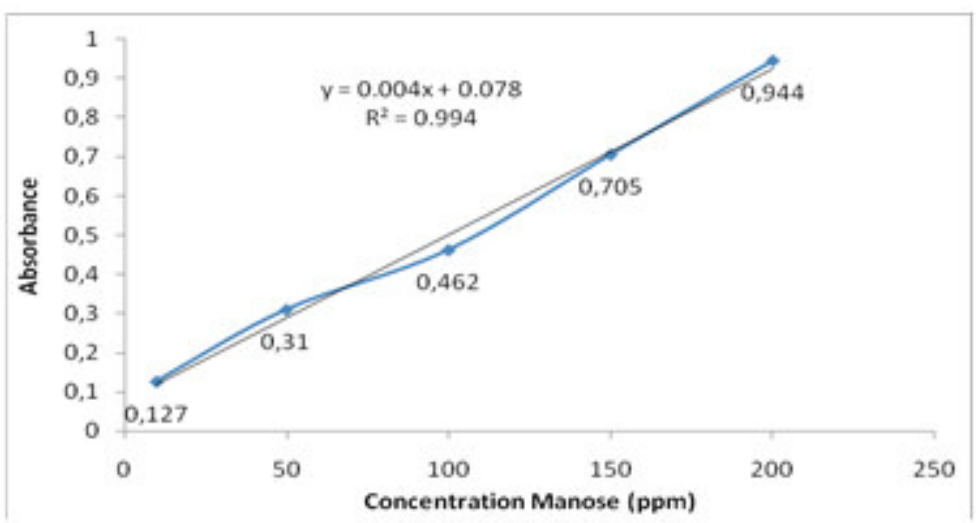

Figure 3. Manosa standard curves

The reducing sugar concentration was determined based on the results from the standard manosa curve. The results of measurements with a spectrophotometer obtained a standard curve with the equation $\mathrm{y}=0.004 \mathrm{x}+$ 0.078 with an $\mathrm{R}^{2}$ value of 0.994 (Figure 3).

3.3.2. Manosa Content from different Fermentation Time

Manosa content from product derived from different fermented time can be seen as Figure 4.

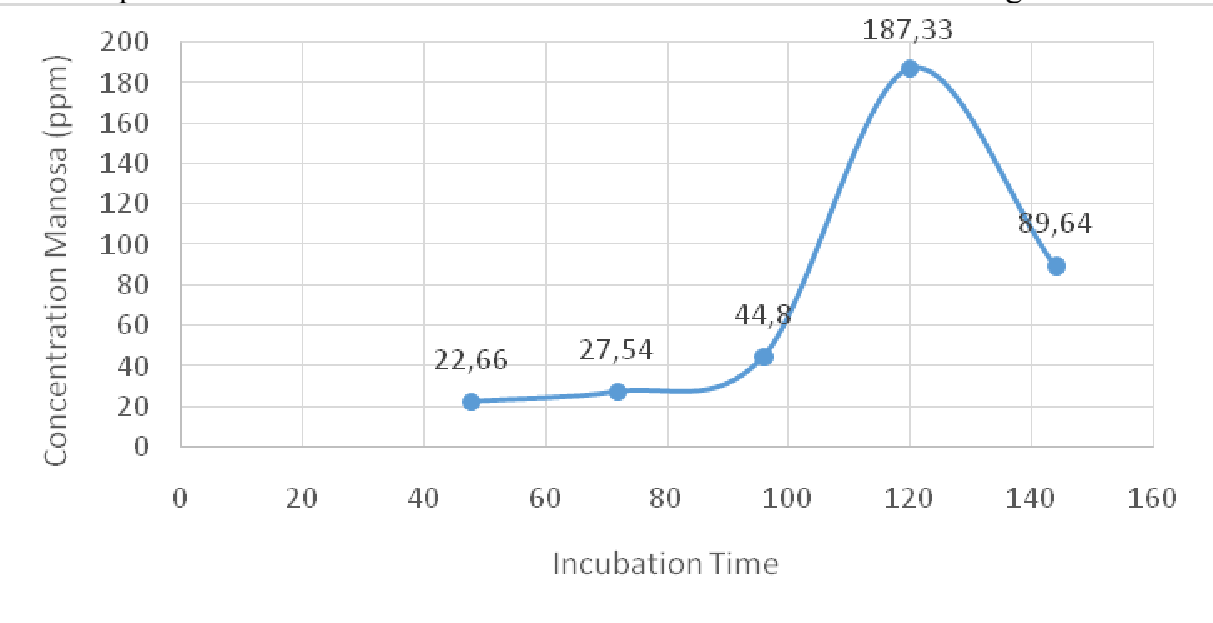

Figure 4. Manosa Content from different Fermentation Time

Based on Figure 4, it can be seen that at 48 hours, the amount of manose produced was still small. It is possible that the nitrogen content of coconut dregs was very small, being $1.45 \%$. The fungus Aspergillus niger took a long time for adaptation to grow and produce the enzyme mannanase for hydrolitic process of galactomannan into a mannose compound. When the time of fermentation was within 120 hours, the amount of mannose compounds produced was $187.33 \mathrm{ppm}$. The increased production was quite significant. It is possible that Aspergillus niger has been in a phase of rapid growth. In this phase the manose produced could already be used as an energy source, leading to produce more enzyme that results in a greater breakdown of galactomannan. This result in the amount of mannose obtained was also increased.

\subsection{Mannanase Enzyme Activity in Fermentation Time Variation}

Mannanase enzyme activity was influenced not only by $\mathrm{pH}$, but also the incubation time during the fermentation stage. In this case, the early stages of fermentation of microorganisms still underwent an adaptation process so that the amount of enzymes produced was still small. This can be seen from Figure 5. following: 


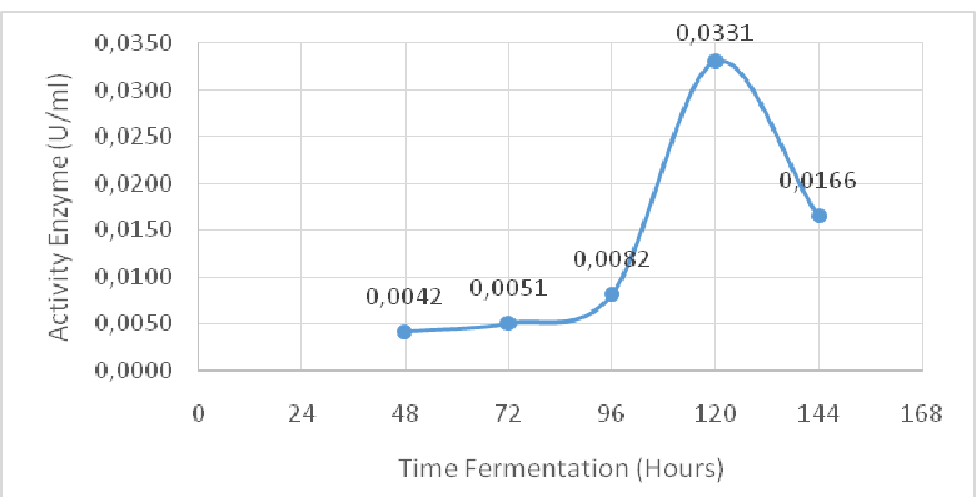

Figure 5. Effect of Fermentation time on Mannanase Enzyme Activity

Based on Figure 5, the activity of the enzyme mannanase increased with increasing fermentation time, in this situation the amount of Aspergillus niger that grows rapidly. This condition results in increased activity of the enzymes produced. The activity of these enzymes will decrease along with the reduced amount of nutrients available. When the amount of nutrients available is getting less, it results in the growth phase of microorganisms. The number of living microorganisms will be reduced. After a 120 hour fermentation time, the activity of the enzyme decreased. This is because, on the first day to the fifth day, microbial growth enters the exponential phase where microbial cells divide rapidly so that the number of microorganisms produced increases and thus mannanase activity also increases. However, after the sixth day, the number of microorganisms decreases, meaning the growth of microorganisms has entered the stationary phase and the phase of death due to nutrients in the medium and the energy reserves in the cell are gone so that the enzyme activity decreases.

According to Supriyati et al, (1998) in the production of mannanase from fermented cassava by Aspergillus niger, it was found that from days 1 to 5 , the fungus experienced continuous growth. In this phase, the microbes grow rapidly and constantly following a logarithmic curve. From days 5 to 7 , the fungi experienced the stationary phase. In this phase, the number of cell populations was constant because the number of cells that grow was the same as the number of cells that die. The cell size in this phase becomes smaller because the cell continues to divide even though nutrients were no longer available. Due to the lack of nutrients, cells may have different compositions with cells that grow in the logarithmic phase. The nutrients added to the fermentation media would be spent during the fermentation process until maximum enzyme activity was produced (Supriyati et al., 1998). The reduction of nutrients resulting in the activity of enzyme production and microorganism growth would decrease. In addition, the contact / reaction time between enzymes and substrate determines the effectiveness of enzymes. The longer the reaction time, the enzymes efficacy will also be more optimum. However, longer the incubation time did not usually correlated with increasing the work of the enzyme. Enzymes will stop working when they reach saturation. This saturation period occurs when the enzyme has been bound to the substrate.

Ariandi et al. (2015) in their research reported that the enzyme activity of mannanase using fermented coconut dregs with Streptomyces casei BF3.1 was obtained at 120 hours of fermentation with an activity of 0.98 U / ml. Sudathip (2013) in his research using the bacterium Penicillium oxalicum KUB-SN2-1 on the extract yeast substrate, obtained the best enzyme mannanase activity $0.11 \mathrm{U} / \mathrm{mg}$ on the fourth day ( 96 hours) and legume bean gum $10.12 \mathrm{U} / \mathrm{mg}$ on the fifth day (120 hours) and copra meal with maximum activity on the fifth day (120 hours) with a value of $0.5 \mathrm{U} / \mathrm{mg}$. Alsarrani (2011) reported that mannanase activity in liquid media using Aspergillus niger obtained the best mannanase activity at $3.0 \mathrm{U} / \mathrm{ml}$ on day six (144 hours). This mannanase activity decreased at 14 days incubation time to $2.16 \mathrm{U} / \mathrm{ml}$. Based on this fact, it appears that mannanase activity differs between one substrate to another substrate. The longer the incubation time was the less activity of the enzyme.

\subsection{Fermented Hydrolyzed Prebiotic Test}

\subsubsection{Prebiotic Test Against Lactobacillus casei}

In this study, the prebiotic test for the lactobacillus casei bacteria was carried out by the dilution method using liquid media and then grown on Nutrient agar media by spread plate. The results showed that the number of bacteria growing on the surface of the solution increased compared to the control (before the addition of prebiotic hydrolyzate compounds). These data can be seen in Table 1 below: 
Table 1. Lactobacillus casei Bacteria after Addition of Extract Fermentation

\begin{tabular}{cccc}
\hline No & Treatment (Hours) & Number of initial colonies & Number of final colonies \\
\hline 1 & $\mathrm{O}$ & $2 \times 10^{7}$ & $35,0 \times 10^{7}$ \\
2 & 24 & $2 \times 10^{7}$ & $32,3 \times 10^{7}$ \\
3 & 48 & $2 \times 10^{7}$ & $34,3 \times 10^{7}$ \\
4 & 72 & $2 \times 10^{7}$ & $30,6 \times 10^{7}$ \\
\hline
\end{tabular}

According to Huebner (2007), prebiotic activity against lactobacillus bacteria has a positive effect on growth. Oligosaccharide carbohydrate compounds were used for bacterial activity as an energy source instead of glucose. Prebiotic activity by these microorganisms occurred in the digestive tract, namely in the intestine. Increasing the growth of lactobacillus casei in the presence of prebiotic compounds was because these bacteria can produce enzymes polyhydrolase and glycosidase (Gibson, 1995). As for the growth, bacteria grew on NA media after 2 days incubation, it appeared that bacteria grew more than control. This can be seen in Figure 6 .

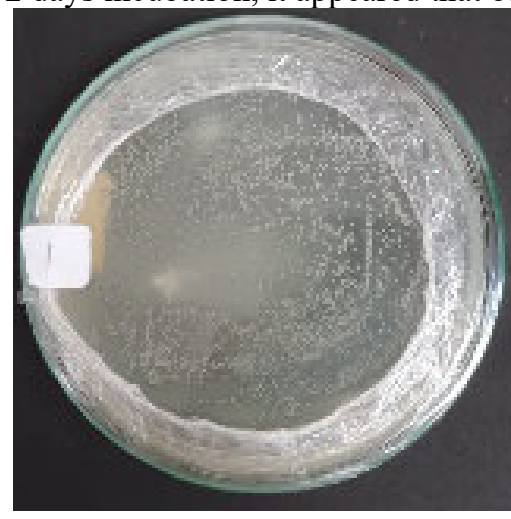

$\mathrm{a}$

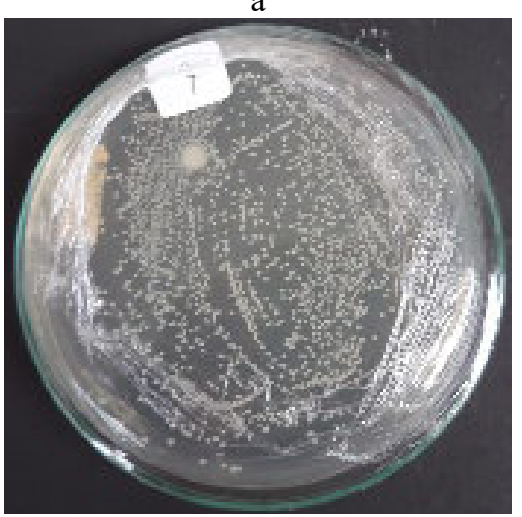

$\mathrm{c}$

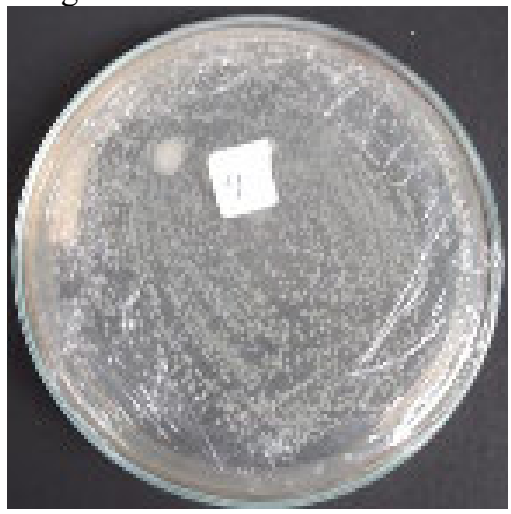

$\mathrm{b}$

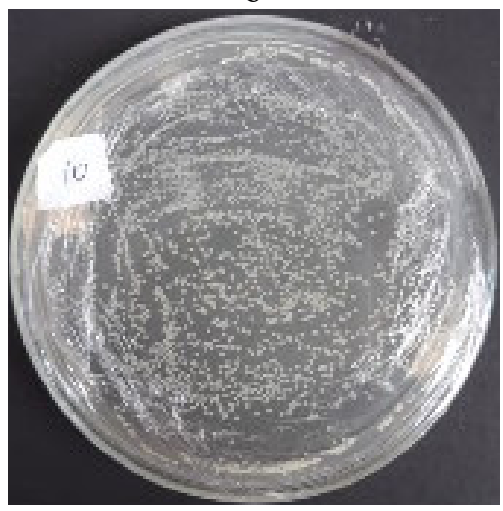

d

Figure 6. Prebiotic Test for Fermentation Hydrolyzate in Lactobacillus casei bacteria

Based on Figure 6, it can be seen that the number of bacteria growing on agar media was very much, being more than 300 cells in each sodium agar medium. The number of bacteria grows more than the control bacteria $\left(10^{2}\right)$. The initial bacteria grown on the PDB media were $10^{7}$. After being diluted as much as $10^{-5}$, so that the numbers of bacteria were $10^{2}$. This means that oligosaccharide hydrolyzate produced in fermentation can provide good nutrition for the growth of lactobacillus casei. This is consistent with the research conducted by Husna (2018) using Jali tuber extract on the growth of Lactobacillus casei bacteria. The addition of $2 \%$ polysaccharide can increase the number of lactobacillus bacteria in the media carried out by the turbidity method, using a spectrophotometer.

Ganzle and Follador (2012) explained that the Lactobacillus casei bacterium is a lactic acid bacterium and is classified as a probiotic bacterium that is able to catalyze polysaccharide or oligosaccharide compounds and use them as an energy source. Carbohydrate metabolism by lactic acid bacteria takes place with the help of glycosidic bond-breaking enzymes such as glycosyl hydrolase. Azmi et al. (2012) reported that probiotic bacteria such as Lactobacillus can survive in the digestive tract due to their ability to live in high acidity.

In this current prebiotic test, a solution of the bacterium lactobacillus casei with a concentration of $10^{7}$ was dissolved in LB media and a total of $4 \mathrm{ml}$ was added with a solution of fermented hydrolyzate as much as $1 \mathrm{ml}$. Media was stirred so that mixture occur between microorganisms that exist in the media with prebiotic compounds. The mixed solution was left for 5 minutes, the interaction process between lactobacillus casei as a microorganism utilizes a hydrolyzate solution as a source of nutrition, leading to the fast growth of bacteria when prebiotic compounds in the media were present. 
An in-vitro research conducted by many researchers also proved that the presence of prebiotic compounds in the gastrointestinal tract can also increase the number of Lactobacillus casei bacteria and other good bacteria. The addition of prebiotics can improve animal health so that it can significantly increase body weight and can also increase the production of lactic acid in the digestive tract. This is because the bacteria Lactobacillus casei are bacteria that can produce lactic acid compounds which also function to create an acidic atmosphere in the digestive tract and to inhibit the growth of pathogenic bacteria such as Escherichia coli and others. The results of the study by Umesh and Preethi (2014) found that the use of banana peel waste in producing lactic acid using Lactobacillus plantarum produced lactic acid of $4.68 \mathrm{~g} / \mathrm{L}$. Likewise, the results of research by Kumar and Shivakumar (2014) showed that the production of lactic acid using the banana peel substrate was able to produce lactic acid of $68 \mathrm{~g} / \mathrm{L}$.

The storage time of coconut dregs fermented with Aspergillus niger in the best condition was considered as day 0 which was then followed by storage of coconut dregs for 24 hours, 48 hours and 72 hours. The results obtained showed that the effect of addition of storage time of coconut dregs was not significant $(\mathrm{P}>0.05)$ on the number of Lactobacillus colonies. This is likely due to the oligosaccharide compounds produced was not increased. So that the prebiotic ability of the fermented product was not different in each treatment

\subsubsection{Prebiotic Test Against Escherichea coli}

Escherichia coli bacteria are one type of bacteria that many live in the digestive tract in poultry. This bacteria can interfere in the digestive process. Disruption of the digestive process is because these bacteria stick to the digestive tract so that the bacteria Lactobacillus casei can not grow and develop properly in the intestinal tract. One of the many methods developed at this time to prevent the presence of Escherichia coli in the gastrointestinal tract is by adding prebiotic compounds in animal feed or drinking water. The mechanism of action of prebiotic compounds against Escherichia coli is that the oligosaccharides could bind E. coli due to the presence of lecithin as a place to stick. In prebiotic testing of Escherichia coli bacteria, it can be carried out by a liquid dilution method followed by a spread plate method. Based on the results of the study obtained the number of bacteria that were given prebiotic solutions reduced in number as Table 2.

Table 2. Total Escherichia coli Bacteria after Addition of Extract Extract Fermentation Enzymatic Variation

\begin{tabular}{cccc}
\hline No & Treatment (Hours) & Number of initial colonies & Number of final colonies \\
\hline 1 & $\mathrm{O}$ & $2 \times 10^{7}$ & $5,3 \times 10^{6}$ \\
2 & 24 & $2 \times 10^{7}$ & $7,3 \times 10^{6}$ \\
3 & 48 & $2 \times 10^{7}$ & $8,3 \times 10^{6}$ \\
4 & 72 & $2 \times 10^{7}$ & $6,0 \times 10^{6}$ \\
\hline
\end{tabular}

The number of E. coli bacteria to test prebiotic activity in this current study was $2 \times 10^{7}$ cell $/ \mathrm{ml}$. For the prebiotic test, the solution of the bacteria was diluted to $10^{-5}$ so that the number of bacteria used for this test was $10^{2}$ colonies. In this stage, $4 \mathrm{ml}$ of Escherichia coli solution was added with $1 \mathrm{ml}$ of extract filtrate. To make the interaction of the prebiotic compound with the solution bacteria, the solution was shaken and left for 5 minutes. A total of $0.1 \mathrm{ml}$ of the solution on the surface was taken and left for 1 day for bacterial growth. 


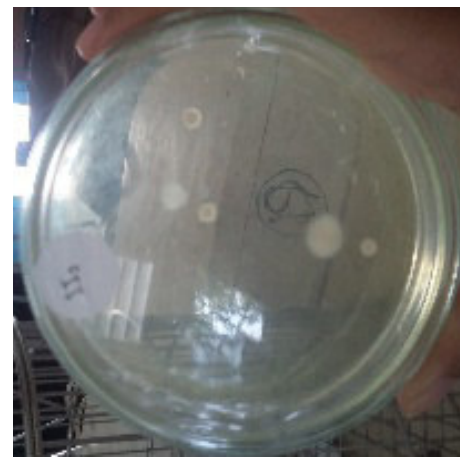

a

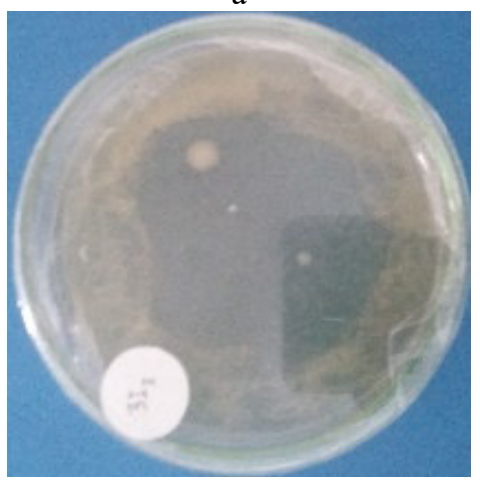

c

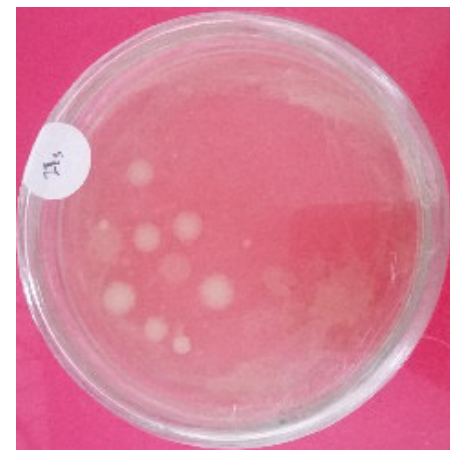

b

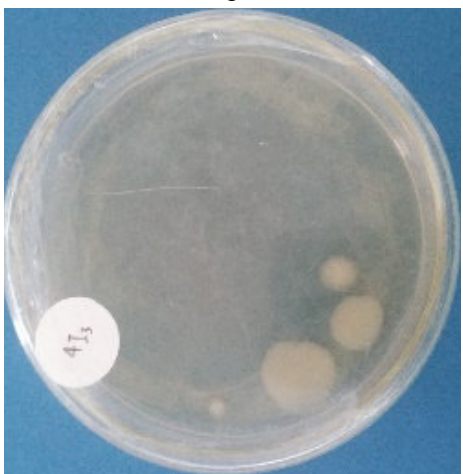

d

Figure 7. Fermentation Hydrolyzed Probiotic Test on Escherichia coli Bacteria

In table 2, it can be seen that the presence of fermentation extract filtrate could reduce the number of bacteria in each treatment from $2 \times 10^{7}$ cell $/ \mathrm{ml}$ to an average of $5.3 \times 10^{6}$ and $8.3 \times 10^{6} \mathrm{cell} / \mathrm{ml}$. This may indicate that the fermentation extract the solution has prebiotic activity. Based on research conducted by Ledy Purwandani et al. (2018), prebiotics from water soluble polysaccharides of durian seeds could decrease Escherichia coli bacteria number from 63.8 to 7.48 at 24-hour incubation time. This occurs because the bacteria Escherichia coli contained lecithin compounds in the cell wall (Indariyah et al., 2013). Lectin compounds found on the surface of the bacteria will bind to the $\mathrm{OH}$ group in the oligosaccharide compound so that the bacteria will be carried to the bottom of the tube. So that the molecules become larger and the number of bacteria on the surface decreased.

Based on Figure 7, it appears that the number of Escherichia coli bacteria in each treatment decreased compared to the control bacteria before the addition of fermentation hydrolyzate solution. In figure (a) the number of bacteria growing on natrium media was 6 cells $/ \mathrm{ml}$ in 0 -hour condition, while (b) 24 hours condition was obtained 9 cells $/ \mathrm{ml}$, (c) 48 hours condition was $3 \mathrm{cell} / \mathrm{ml}$ and (d) the condition of 72 hours was obtained as much as 4 cells $/ \mathrm{ml}$. The number of Escherichia coli bacteria on the surface of the solution media decreased because these bacteria were bound by oligosaccharide molecule and carried to the bottom of the tube. This is consistent with the binding pattern of bacteria in the digestive tract using prebiotic compounds. In this case, the bacteria in the digestive tract decrease in number because it was carried along with feces out of the digestive tract.

The results of the statistical test of fermented products incubated with the length of storage for 24 hours, 48 hours and 72 hours yielded almost no different from the time of 0 hours. The results obtained indicate that the effect of the addition of duration of storage on prebiotic activity against Escherichia coli colonies did not significantly $(\mathrm{P}>0.05)$ affect. This is because the enzymes produced had small activity, beings $0.0331 \mathrm{U} / \mathrm{ml}$. In addition, it is also possible that the enzymes produced in the fermentation process have been damaged due to storage conditions that have passed their shelf life.

\section{Conclusions}

The results of the delipidation process could decrease lipid content to $0.77 \%$ and the deproteination process could bring down the crude protein of coconut dregs to $1.45 \%$. The highest mannanase activity was found when coconut dregs were fermented for 120 hours with a value of $1.0331 \mathrm{U} / \mathrm{ml}$. Hydrolyzate produced during incubation had a prebiotic activity by increasing the population Lactobacillus casei and decreasing population of Escherichia coli. Lactobacillus casei bacteria increased from $2 \times 10^{7} \mathrm{CFU} / \mathrm{ml}$ to between $30.6 \times 10^{7} \mathrm{CFU} / \mathrm{ml}$ and $35.0 \times 10^{7} \mathrm{CFU} / \mathrm{ml}$, whereas Escherichia coli bacteria decreased from $2 \times 10^{7} \mathrm{CFU} / \mathrm{ml}$ to between $5.3 \times 10^{6}$ $\mathrm{CFU} / \mathrm{ml}$ and $8.3 \times 10^{6} \mathrm{CFU} / \mathrm{ml}$. 


\section{References}

Ariandi, Yopi, Y \& Meryandini, A. (2015). Enzymatic hydrolysis of copra meal by mannanase from Streptomyces sp. BF3.1 for the production of mannooligosacharides. Hayati J. Biosci. 22: 79-86.

Azmi, A.F., Mustafa, S., Hasim, D.D. Manap, Y., A, (2012). Prebiotic Activity of Polisaccharide extracted from ganthocholoa levis, (buluh Betting) shoots Molecule, Vol 17(2): 1635-1651.

Bahri S, Sundu B, \&.Aprianto, M. R. (2019). Mannanase activity produced through fermentation of coconut flour at various $\mathrm{pH}$ by Aspergilus niger, International Seminar on Science and Technology 2018, IOP Conf. Series: Journal of Physics: Conf. Series 1242.

Buxbaum, E. (2007). Fundamentals of Protein Structure and Function. Spinger, USA

Felicia, A., Omoloda, A.O \& Onilude, A. (2013). Production, Purification and characterization of a mannanase by Aspergillus niger through solid state fermentation (SSF) of Gmelina Arborea shavings. African Journal of Microbiological Research, 7: 282-289

Ferket, P.R., Park, C.W \& Grimes, J.L.,(2002). Benefits of dietary antibiotics and Mannanoligosaccharide supplementation for poultry. Multi-State Poultry meeting, North Carolina State University,Raleigh.

Gibson, G.R., Roberfroid, M.B., (1995). Dietary Modulation of the Human Colinic Microbiota: Introduction the Concept Prebiotiks, J Nutr 125: 1401-1412

Ganzle, M. G \& Follador, R. (2012). Metabolisms of Oligosaccharides and starch in Lactobacilli: A review. Frontiers in Microbiology, 3: 340.

Huebner, J. Wehling, R.L. \& Hutkin R.W., (2007). Fungtional Activity of commercial Prebiotic, International Diary Jurnal 17: 770-775

Husna, A. 2018, Potensi Jali (CoiLachryma-Jobi L) Sebagai Prebiotik Terhadap Pertumbuhan Bakteri Asam Laktat, Jurnal Telonologi Pertanian Vol 19(2): 75-84.

Indariyah, Taufik N.J, \& Ismunarti, D.H. (2013). Studi pengunaan Mannanoligosakarida (MOS) terhadap kelulus hidupan dan pertumbuhan Artamia, Journal of Marine Research, Vol. 2 no. 3 tahun 2013

Ishihara, N., Shu, D.C., Akachi, S. \& Juneja,L.R., (2000). Preventive effect of partially hydrolyzed gur gum on infection of Salmonella enteridis in young and laying hen. Poult. Sci. 79:689-697.

ISO 7218, (2007). Microbiology of Food and Animal Feeding Stuff-General requirement and guidance for microbiological examination

Kumar, R., \& Shivakumar, S. (2014).Production of L-Lactic acid from starchand food waste by amylolytic Rhizopusoryzae MTCC 8784. International Journal of ChemTech Research, 6(1),527-537.

Khuwijitjaru P, Watsanit K, \& Adhaci S, (2012). Carbohydrate content and composition of product from subcritical water treatment of coconut meal, Industrengchem 18: 225-229

Kusakabe, I. \& Takashi, R.(1988). Enzymatic preparation beta 1-4 mannooligosaccharides and beta 1-4 glucomannooligosaccharides. Methods in Enzymology, 160: 518-523

Lee, N.S., (2007). The Production of Fungal Mannanase, cellulose and xylanase using Palm Kernel as a Substrat, Walailak Journal sciences \&Technologivol 4(1): 67-82

Lehninger, A. L. (1998). Dasar-DasarBiokimia. Terjemahan, M. Thenawidjaja. Jakarta: Pustaka Sinar Harapan

Lorenzo, L. K. (2008). Improving The Solubility of YellowMustard Precipitated Protein Isolate in Acidic AqueousSolutions. Departement of Chemical Engineering andApplied The Folin Phenol Reagent. The JournalBiological Chemistry $193: 265-275$

Meddiati F.P., (2010). Kandungan Gizi dan sifat fisik tepung ampas kelapa sebagai bahan pangan sumber serat,Teknubuga vol. 2 No. 2

Miller G.L. (1959). Use of dinitrosalicylic acid reagent for determination of reducing sugars. Anal Chem 31: 426-428

Miskiyah, Muliawati I. \& Winda H., (2010). Pemanfaatan ampas kelapa Limbah Pengolahan Minyak Kelapa Murni menjadi pakan, Makalah seminar nasional Teknologi Peternakandan Vetereiner, 2006, Balai Besar Penelitian dan Pengembangan Pascapanen Pertanian, Bogor

Phanwipa P. Sunee, N., Arunee I., and Suttipun K., (2015). Defatted copra meal hydrolisate as a novel candidate for prebitics, Journal of the hia and development valaya in royal patronage pharmacist, vol 10(3): $1-10$

Purwadani, L., Fenny, I \& Libertus, D. (2018). aktivitas prebiotik polisakarida larut air biji durian in vitro pada lactobacillus plantarum, l.acidophilus dan bifidobacterium longum, Food tech Jurnal Teknologi Pangan Volume 1(1): 14-24.

Sarjono, M, Bambang S. \& Hendaryati D.D. (2013), Komoditi Kelapa 2011-2013, Sekretariat Ditjen Perkebunan, Direktorat Jenderal Perkebunan Kementerian Pertanian, Jakarta

Sudathip T. C., Katesarin, B., Apinya, P., Tasanee, S,. Pichamon, Jantawon, K., \& Nitisinprasert, S.. (2013). Optimization of extracellular mannanase production from Penicillium oxalicum KUB-SN2-1 and application for hydrolysis property, Songklanakarin J. Sci. Technol. 35 (1), 17-22.

Suhardiyono, L., (1988). Tanaman Kelapa, Budidaya dan Pemanfaatannya, Penerbit Kanisius, Yogyakarta, 153- 
156.

Supriati T. Pasaribu, H. Hamid, dan A sinurat, (1998). Fermentasi bungkil inti sawit secara substrat padat dengan menggunakan aspergilus niger, Jurnal ilmu ternak dan Veteriner, vol. 3(3) 165-169.

Tanyilidizi, M. Saban, D. Ozer \& Elibol. (2007). Production of Bacterial $\alpha$-amylase by mylolliquefacien Under Solid Substrate Fermentation. Biochemical Engineering Journal Volume 37, Issue 3.294-297

Turner, J.L., Dritz, P.A.S \& Minton, J.E.(2000). Alternatives to conventional microbials in swine diets. Prof. Anim.Sci. 17: 217-226.

Umesh, M. \& Presthi, K. (2014). Fermentative utilization of fruit peel waste of lactic acid production by Lactobacillus planatarum. Indian Journal of Applied Research, 4: 449-451.

Vani, B. \& Zayas, J. F. (1995). Wheat Germ Protein Flour Solubility and Water Retention. J. Food Sci., 60: $845-848$ 